LENKA NÉMETH VÍtovÁ

Uniwersytet im. Adama Mickiewicza w Poznaniu

\title{
Terytorialna historia literatury środkowoeuropejskej jako spuścizny literackiej i kulturowej monarchii Habsburgów
}

Martin C. Putna (2018), Obrazy z kulturních dějin Střední Evropy (Obrazy z dziejów kulturowych Europy Środkowej), Vyšehrad, Praha.

Martin Cyril Putna (ur. 1968), historyk i krytyk literacki, profesor antropologii społecznej i kulturowej wykładający na Uniwersytecie Karola w Pradze, jest autorem lub współautorem ponad 30 książek, w tym wielu wywołujących spore zainteresowanie i liczne dyskusje. W swojej ojczyźnie znany jest również poza kręgami naukowymi za sprawą prodemokratycznego zaangażowania obywatelskiego (m.in. w ramach kampanii wspierających demokratyczny rozwój Ukrainy lub potępiających prawicowy ekstremizm); szeroki rozgłos towarzyszył również jego otwartej obronie wartości chrześcijańskich przy jednoczesnej obronie homoseksualizmu (por. Putna 2012).

W środowisku naukowym Putna zyskał uznanie i podziw przede wszystkim dzięki monumentalnej trylogii, poświęconej trzem kolejnym okresom dziejów czeskiej katolickiej literatury pięknej (1848-1918, 1918-1945, 1945-1989), w której omawia zarówno prozę, poezję, dramaturgię, eseistykę i literaturę wspomnieniową, jak również opracowania na ich temat (Putna 1998, 2010a, 2017). Poszczególne tomy stanowią pierwsze od kilku dziesięcioleci systematyczne opracowanie tematu, należy jednak zaznaczyć, że ich treść nie ogranicza się zaledwie do „ewidencjonowania” faktów i zjawisk - celem, jaki przyświecał 
powstaniu trylogii, było bowiem zaprezentowanie panoramicznego obrazu rozwoju literatury tego obszaru przy jednoczesnym uwzględnieniu należytej historycznoliterackiej szczegółowości (co zaowocowało pokaźną objętością każdej z książek: kolejno 802, 1392, 1024 strony).

Badacz dysponuje erudycją interpretacyjną opartą na imponującej wiedzy, która nie ogranicza się do samej tylko literatury pięknej, co udowodnił też w publikacjach na temat wybranych osobowości czeskiej kultury - m.in. Jaroslava Durycha, Karela Schwarzenberga i Václava Havla (Putna 2003, 2007, 2011). Publikacja poświęcona ostatniemu $\mathrm{z}$ wymienionych spotkała się, co zrozumiałe, z najliczniejszym odzewem. Portret Havla pióra Putny - w latach 2008-2011 pełniącego funkcję dyrektora Biblioteki Václava Havla, założonej w 2004 roku na wzór bibliotek prezydenckich w Stanach Zjednoczonych - jest próbą uchwycenia poszczególnych różnorodnych i często sprzecznych idei, które formowały słynnego Czecha, począwszy od dzieciństwa spędzonego w niezwykle nowoczesnej i intelektualnie ukierunkowanej rodzinie burżuazyjnej, poprzez okres dojrzewania i dorosłości w warunkach socjalizmu (o kilku „twarzach”), aż po czasy prezydentury. Również $\mathrm{w}$ tym studium autor proponuje szerszy kontekst interpretacyjny: podkreślając dążenia Havla do uduchowiania własnego narodu, wiąże go z jego wielkimi poprzednikami: pierwszym prezydentem Czechosłowacji Tomášem Garriguem Masarykiem oraz cesarzem Karolem IV, przekonując, iż Havel, podobnie jak oni, pozostawił dziedzictwo ideowe, z którego będą korzystać kolejne pokolenia. Emocjonalność, a wręcz patetyczność tej tezy należy osadzić w kontekście czasowym - książka ukazała się w 2011 roku, kiedy to poważne problemy zdrowotne coraz częściej uniemożliwiały Havlowi aktywny udział w życiu publicznym - zresztą pod koniec tego roku najbardziej znany spośród czeskich (i czechosłowackich) prezydentów zmarł.

Inne prace Putny również zdradzają wyjątkowy zapał badawczy, a jednocześnie brak obaw przed ujawnianiem własnej postawy światopoglądowej lub osobistego stosunku do rozważanych zagadnień. W ostatnich latach skupił się on na temacie, którym zajmuje się od czasów swoich juweniliów, czyli na powiązaniach między kulturą a religią. W tomie poświęconym kulturze Stanów Zjednoczonych (będącym owocem m.in. rocznego pobytu w tym kraju) badacz omawia - w formie układających się w panoramiczny obraz esejów naukowych wpływ ważniejszych prą̧ów religijnych (katolicyzmu, judaizmu, purytanizmu, kwakryzmu, ewangelicyzmu, mormonizmu, buddyzmu itd.) na amerykańskie życie społeczne i kulturę, w szczególności na literaturę i film (Putna 2010b). Podobny układ kompozycyjny charakteryzuje również „bliźniaczą” książkę, poświęconą kulturze rosyjskiej (znanej mu bardzo dobrze choćby dlatego, że studiował filologię rosyjską i obronił doktorat $\mathrm{z}$ tej dziedziny). W tomie tym 
Putna wskazuje i wyjaśnia główne elementy dziejów rosyjskiej kultury i duchowości od czasów Rusi Kijowskiej aż po Pussy Riot, poświęcając szczególną uwagę Ukrainie (m.in. uwrażliwia na niewłaściwe określanie jej jako „Małorosji”) i nie kryjąc przy tym swoich głębokich przekonań demokratycznych (Putna 2015).

Ostatnią, trzecią już część dotyczącą relacji między kulturą a religią wydał Putna w 2018 roku pod tytułem Obrazy z kulturních dějin Střední Evropy (Obrazy z dziejów kultury Europy Środkowej). W następnym roku została ona nominowana do najbardziej prestiżowej czeskiej nagrody literackiej Magnesia Litera w kategorii „literatura naukowa i popularnonaukowa” (pomimo iż tematyka środkowoeuropejska w tamtym roku miała akurat silną reprezentację - po czesku ukazał się również wybór esejów znanego francuskiego politologa i historyka zajmującego się tematyką środkowo- i wschodnioeuropejską - por. Rupnik 2018).

W pierwszym zdaniu wstępu Putna wskazuje na impuls, który przyczynił się do powstania książki: „W drugim dziesięcioleciu dwudziestego pierwszego wieku Czesi ponownie zastanawiają się nad swoim miejscem w świecie"1 (Putna 2018: 11). Ta zwięzła diagnoza dyskursu publicznego ostatnich lat nie dotyczy zresztą tylko Republiki Czeskiej, ale i innych krajów Europy Środkowej, w których nasila się nostalgia za czasami sprzed transformacji ustrojowych końca lat dziewięćdziesiątych XX wieku. W odpowiedzi na tak postawiony problem Putna prezentuje spektakularną panoramę wielokulturowości, wielojęzyczności i wielowyznaniowości poszczególnych regionów Europy Środkowej (rozumianej przez niego jako spuścizna kulturowa Austro-Węgier), by móc dalej naszkicować jej „historię idei”; pozwala to na pełniejszą refleksję nad przeszłością tego regionu, a co za tym idzie na budowanie przyszłości w oparciu o te (zapomniane, a niekiedy wyparte) doświadczenia.

We wstępie autor wyjaśnia również swoje podejście metodologiczne do tematyki środkowoeuropejskiej, nazywając je „literacko-geograficzną hermeneutyką” (Putna 2018: 17), którą opisuje jako „osadzenie narodów i konfesji, autorów i utworów w określonym kraju, w konkretnej krainie” (Putna 2018: 17). Relację danej lokalizacji z utworem rozumie nie jako „pozytywistyczno-regionalistyczno-socjologiczny determinizm" (Putna 2018: 17), ale jako oddziaływanie szerokiego kontekstu towarzyszącego temu konkretnemu miejscu na nowo powstający utwór, a następnie wzbogacanie przez ów utwór tego kontekstu o nowe znaczenia, które będą dalej współtworzyć kontekst kolejnych utworów.

Następujące po wstępie 17 rozdziałów poświęcono charakterystycznym zjawiskom literackim i religijnym poszczególnych obszarów niegdysiejszej monarchii austro-węgierskiej. Kolejno przedstawiane są: Czechy i Babunia (1855)

1 Wszystkie przekłady cytatów z recenzowanej książki pochodzą od autorki recenzji. 
Boženy Němcovej, Morawy i literatura katolicka, Śląsk i Angelus Silesius, Górna Austria i Adalbert Stifter, Dolna Austria i Otto Weininger, Styria - Karyntia Land Salzburg i Karl Heinrich Waggerl, Tyrol - Vorarlberg i antyk w operze, Kraina i antyk u Słowian, Pobrzeże Austriackie i motyw śmierci, Węgry i Péter Eszterházy, Górne Węgry i luteranizm, Siedmiogród i unitarianizm, Chorwacja i walka z islamem, Dalmacja i głagolica, Galicja i Bruno Schulz, Bukowina i Gregor von Rezzori, Bośnia i Ivo Andrić.

Jak przystało na rozprawę, której autor zadeklarował zamiar „geograficznego" spojrzenia na literaturę, każdy rozdział otwiera mapka omawianego terytorium oraz krótkie wprowadzenie historyczne. Mapki są proste - oprócz granic zaznaczono na nich tylko kilka najważniejszych centrów kulturowych oraz podano jedną wybraną informację, o której mowa w tekście (np. w przypadku Śląska są to kierunki emigracji, w odniesieniu do Węgier - dwie nałożone na siebie mapy: Węgier z czasów austro-węgierskich i obecnego państwa, zaś schemat Galicji pokazuje m.in. tereny zamieszkałe przez Hucułów). Początkowe zdania każdego rozdziału, mówiące o historii danego obszaru, są jakby tekstowym odzwierciedleniem mapek: podają kluczowe, niepodważalne fakty historyczne, autor jednak nie obawia się uzupełniać tych danych o własne opinie, nawet jeśli uderzają one $\mathrm{w}$ istotę powszechnie przyjętego kanonu historycznego. Przykładowo krytykuje swoich rodaków, którzy chcą pamiętać jedynie o niesprawiedliwości wyrządzonej im przez Niemcy, Francję i Anglię w Monachium krótko przed II wojną światową, a zapominają o własnej zaborczości we wcześniejszym okresie:

Czesi po 1918 roku rozrastali się na zachodzie według zasady historycznej, a na wschodzie według kryterium etnicznego, i to dodatkowo niesprawiedliwie, bo pochłaniając pół miliona Węgrów. W 1938 roku zostali więc surowo ukarani, tracąc terytoria (Putna 2018: 173).

Badacz nie szczędzi jednak żadnej ze stron:

Węgierscy Węgrzy w drugiej połowie XIX wieku podjęli próbę zhungaryzowania Węgrów słowackich, rumuńskich i wszelkich innych lecz właśnie to spowodowało osłabienie ich lojalności wobec korony świętego Stefana. Ostatecznie zaś doprowadziło do „Trianon” (Putna 2018: 173).

Rozdziały - poza informacjami wstępnymi - zawierają analizę i interpretację wybranych przez autora elementów kultury związanych z poszczególnymi 
obszarami. Putna przedstawia w nich własne - w tym zaskakujące, a nieraz prowokujące (by nie powiedzieć obrazoburcze) - odczytania literatury i kultury (jak to, w którym tytułową bohaterkę Babuni Němcovej, książki należącej do czeskiego dziewiętnastowiecznego kanonu literackiego, określa mianem „bodhisattwy”, altruistycznej buddyjskiej istoty niosącej pomoc innym - Putna 2018: 30). Śmiałym tezom, interpretującym zjawiska istotne dla omawianej przez autora kultury, trudno odmówić oryginalności (twierdzi on np. że popularne wycieczki szkolne do doliny, w której toczy się akcja wspomnianej powieści, miałyby w zlaicyzowanym społeczeństwie zastępować pielgrzymki - Putna 2018: 32, lub też przekonuje, że ową babunię, jako postać archetypową, należy łączyć ze św. Ludmiłą, babką św. Wacława, a częściowo również z mitologiczną Tetką znaną z kroniki Kosmasa - Putna 2018: 38).

Imponuje szeroki zakres materiałowy i rozpiętość czasowa zagadnień, jakie obejmuje dzieło: od mitów, legend i hagiografii, poprzez barok (Nikola IV Zrinski i Nikola VII Zrinski), oświecenie (Ioan Budai-Deleanu), biedermeier (Adalbert Stifter), aż po modernizm (Jože Plečnik) i postmodernizm (Péter Eszterházy), odnosi się ono również do czasów najnowszych (np. do protestów na Ukrainie z 2013 roku). Okazała jest również lista nazwisk pisarzy, którzy pojawiają się w książce w kontekście swojej twórczości i/lub biografii: z literatury światowej są to np. (w porządku alfabetycznym) Jurij Andruchowycz, Paul Celan, James Joyce, Mychajło Kociubynski, Robert Musil, Taras Prochaśko, Joseph Roth, Leopold Sacher-Masoch, Italo Svevo, zaś z literatury polskiej np. Bruno Schulz, Zbigniew Herbert, Jan Lam, Krzysztof Varga.

Przez ów wykład literackiej i kulturowej historii regionów przebija miejscami - wyraźnie, choć nie w sposób dominujący - wnikliwe spojrzenie teologiczne (które badacz wyniósł zapewne ze swoich studiów): w jednym miejscu autor upomina się o pomijany w dziejach duchowości śląskiej ewangelicki Kościół Jezusowy w Cieszynie (Putna 2018: 65 i nast.), gdzie indziej zaś o jedną z pierwszych regulacji prawnych zapewniających swobodę wyznania - edykt z Turdy, ogłoszony w 1568 roku w Siedmiogrodzie, którego inicjatorem był zresztą Jan II Zygmunt Zápolya, syn Izabeli Jagiellonki (Putna 2018: 221). Podkreśla również - niekoniecznie oczywistą dla rodzimego czytelnika - tolerancyjność Polski w dobie renesansu i baroku:

[Rzeczpospolita - L.N.V.] była religijnie niewiarygodnie bogata i tolerancyjna, zapewniając wolność wyznaniową obok katolików również luteranom, kalwinom, na wschodzie ukraińskim i białoruskim prawosławnym, w małych enklawach również muzułmańskim Tatarom, w większych zaś oczywiście Żydom - a dodatkowo przyjmując 
„heretyków” wypędzanych z innych europejskich krajów, m.in. unitarian (Putna 2018: 66).

Z tekstu przebija niewątpliwy szacunek, jaki autor żywi wobec wszystkich omawianych kultur. Książka jest podzielona na rozdziały odpowiadające poszczególnym regionom, jednak Putna wielokrotnie odwołuje się zarówno do części wcześniejszych, jak i następnych, gdy dotyka zagadnień związanych z innymi obszarami - pozwala to podkreślić złożoność relacji łączących utwory, autorów, ruchy i idee. Dbałość o „równouprawnienie” poszczególnych kultur została wyrażona też pośrednio - nazwy geograficzne są podawane w kilku językach: obok języka czeskiego również po polsku, niemiecku, ukraińsku lub rosyjsku (np. Lwów - Putna 2018: 247, Stanisławów - Putna 2018: 280); ponadto godna podkreślenia jest również skrupulatna wręcz poprawność tego zapisu.

Znajdujące się w książce teksty są uzupełnione przydatnymi narzędziami pomocniczymi, takimi jak nota edytorska (niektóre rozdziały powstały na podstawie artykułów opublikowanych wcześniej, inspirację stanowił również cykl popularnonaukowych audycji przygotowywanych przez autora dla Czeskiego Radia), krótkie streszczenie w języku angielskim, indeks nazwisk oraz - tu znów ślad terytorialnego spojrzenia na historię - indeks nazw geograficznych. Bibliografia została ujęta w przypisach: obok źródeł czeskojęzycznych, najczęściej cytowane i przywoływane są opracowania w języku niemieckim, ale znajdziemy też liczne odwołania do innojęzycznej literatury przedmiotu (po angielsku, polsku, ukraińsku, rosyjsku, włosku itd.).

Omawiając bardziej lub mniej znane fakty z zakresu historii kultury oraz współczesności pewnego obszaru Europy Środkowej, książka ta podejmuje zarazem temat wielokrotnie już poruszany - kwestię tożsamości kulturowej mieszkańców tego terenu. W sposób świadomy i jawny nawiązuje ona do idei zawartej w Dunaju (1986) Claudio Magrisa (Putna 2018: 14), ale można w tym miejscu przywołać również wiele innych, eseistycznych pozycji, dotyczących tej problematyki, choć zasadniczo odmiennych ${ }^{2}$ - spośród autorów polskich np. Rodzinna Europe (1959) Czesława Miłosza, Poruszona mape (2016) Przemysława Czaplińskiego, a z czeskich choćby antologię $V$ kleštích dějin (W szponach historii; 2009) przygotowaną przez Jiřego Trávníčka, a w niej esej jego autorstwa, lub też popularnonaukowe Czeskie sny (2010; wyd. polskie - poszerzone: 2014) Pavla Kosatíka³.

2 Na temat odmienności koncepcji Europy Środkowej zob. Kledzik 2015.

3 Czeskiemu czytelnikowi tytuł ten kojarzy się również z pozycją z kanonu szkolnego, książką Obrazy z Rus (1843-1846), w której Karel Havlíček Borovský, jeden z „ojców 
Podsumowując, warto docenić przede wszystkim zaprezentowaną przez autora propozycję przestrzennego ujęcia tematyki, nieoczywistą dla docelowego czeskiego czytelnika ze względu na przeważającą w tamtejszym środowisku koncepcję Europy Środkowej, a słabą obecność idei Europy Środkowo-Wschodniej. Dla wielu rodaków autora odkrywcze mogą być więc środkowoeuropejskie „Wycieczki” na Południe i na Wschód (jak np. rozdział VII na temat Tyrolu i Vorarlbergu, skupiony na Monteverdim i operze, lub rozdział XV poświęcony Galicji, przywołujący również Hucułów i Łemków).

Inspirujący jest również cel, jaki przyświecał koncepcji powstania książki: powiązanie $\mathbf{w}$ nową sieć elementów zarówno dobrze znanych $\mathrm{z}$ tradycyjnych ujęć historii literatury i kultury narodowej, jak i tych, które dotychczas były niesłusznie marginalizowane lub wręcz pomijane. Dlatego też obok nadrzędnego porządku geograficznego, jaki kierował organizacją tomu (jeden rozdział - jedno terytorium), zastosowano również (na tyle przekrojowo, na ile to możliwe) układ chronologiczny (od najstarszych utworów literackich po współczesne), przy omawianiu poszczególnych zagadnień posłużono się zaś kryterium ogólnokulturowym (na równi z wątkami literackimi analizuje się również sytuację wyznaniową, architekturę, operę itp.). Specyficzna mozaika, jaką jawi się nam dzięki lekturze całokształt zjawisk, określających każdy z regionów, pozwala bardziej kompleksowo pojąć zarówno historię literacką i kulturową, jak i obecną sytuację danego obszaru. Tym samym autor opowiada się zdecydowanie za przyjęciem nowej, terytorialnej historii literatury (wpisującej się w area studies), będącej - jak pokazuje na licznych przykładach wiążących historię regionu z jego najnowszymi literackimi, kulturowymi, ale również politycznymi kolejami losu - nie tylko drogą do uspójnienia często przerywanej historii wielu regionów Europy Środkowej, ale przede wszystkim kluczem do odczytania jej dynamicznej ponowoczesności.

Szeroko zakrojona panorama literatury Europy Środkowej pociąga za sobą, co oczywiste, konieczność subiektywnego wyboru tematów i poruszanych wątków, posługiwanie się pewnymi uproszczeniami i uogólnieniami w argumentacji, jak również zwięzłe formułowanie autorskich tez (np. tej o realizmie magicznym; Putna 2018: 283 i nast.). Zdecydowanie najsilniejszą stroną tomu jest ujęcie zjawisk literatury i kultury w aż tak szerokie ramy, zarówno przestrzenne, jak i czasowe. Ma to na celu wychwycenie pewnych elementów historii idei,

założycieli” czeskojęzycznej publicystyki, dzielił się swoimi krytycznymi refleksjami z podróży po Rosji, co stanowiło odosobniony głos na tle panującego wówczas zafascynowania panslawizmem. 
lecz stanowi zarazem najłatwiej podlegający krytyce aspekt tomu. Przykładowo, można poddać pod dyskusję informację, jakoby na Węgrzech łacina aż do połowy XIX wieku miała pełnić funkcję żywego języka w kręgach intelektualistów (Putna 2018: 172). Była ona raczej językiem kontaktów pisemnych lub odgrywała rolę lingua franca, podobnie jak obecnie język angielski; tym samym teza autora o destrukcyjnych dla Węgier skutkach zastąpienia uniwersalistycznej łaciny językiem węgierskim w życiu publicznym elit traci na wyrazistości: nie tyle odejście od łaciny, co nasilająca się - zarówno wśród Węgrów, jak i innych grup etnicznych - aktywność ruchów narodowych prowadziła nieuchronnie do zaniku centralistycznych mocarstw wielonarodowych. Wątpliwości budzi również próba stworzenia przez autora jego własnego konstruktu Europy Środkowej, nazwanego przezeń „austriacką misją cywilizacyjną”, o co pokusił się w podsumowaniu. Tymczasem w całej książce (poza krótkim zakończeniem) autor ukazuje procesy polegające zarówno na przejmowaniu elementów i wywieraniu wpływów, jak też na różnicowaniu się i konfliktowaniu, a także na współistnieniu i nakładaniu się na siebie pewnych obszarów literatury i kultury - czyli mechanizmy zachodzące nie bez politycznych ingerencji imperium, ale zdecydowanie nie wyłącznie dzięki nim.

Pomimo tego polemicznego potencjału, Obrazy z kulturních dějin Střední Evropy Putny sugerują, jak nadać nowy kierunek - zamkniętej w zaklętym kręgu - dyskusji o konstrukcie Europie Środkowej. Eseistyczne szkice Putny, ukazujące złożoną, pełną wzajemnych powiązań historię kultury (pomimo fragmentaryczności i subiektywności pewnych odczytań), są ewidentnie krokiem w stronę rozumienia literatury i kultury jako medium pamięci. (Kiedy w odniesieniu do książki Neprosti (Niezwykli, 2002) Tarasa Prochaśko Putna stwierdza: „Tym, co pozostaje, jest pamięć i fantazja - umiejętność opowiadania o tym wszystkim" - Putna 2018: 285, to tak jakby w pewnym sensie definiował własną narrację $i$ swoje eseistyczne spojrzenie na wybrane ogniwa historii idei Europy Środkowej.) Ukazując różnorodność kanonów literackich i kulturowych, funkcjonujących w wybranych przez siebie regionach Europy Środkowej, jak i mnóstwo zjawisk, które się im wymykają, autor liczy, zdaje się, na sprawcze oddziaływanie zatrzymanej w niej pamięci (za Astrid Erll genitivus objectivus; Erll 2011). Postanowił więc wydobyć z cienia i wysunąć na pierwszy plan mniej popularne utwory oraz zaproponować nowe, autorskie odczytania tych bardziej znanych, demonstrując dzięki temu mechanizm zarówno odtwarzania, jak i wytwarzania pamięci za pośrednictwem literatury. Prezentowane w książce Putny podejście wpisuje się w działania określone przez Erll jako refleksyjna retoryka pamięci, mające na celu ożywianie i rekonstruowanie określonych 
wersji przeszłości w zestawieniu ze współczesnością (Erll 2011). Badający Szoah Michael Rothberg wyraził

przekonanie, że tylko nieograniczona koncepcja podmiotów pamięci i historycznej odpowiedzialności może wyjaśnić różne rodzaje dziedzictwa, które nakładają się na siebie, tworząc spuściznę Europy - Europy postkolonialnej, postsocjalistycznej, postnarodowo-socjalistycznej, a zarazem postmigracyjnej (Rothberg 2013: 165).

Putna swoją książką realizuje dokładnie to stanowisko, proponując Czechom (i nie tylko im) ich miejsca na świecie.

\section{| Bibliografia}

Erll Astrid (2011), Memory in Culture, przeł. Sara B. Young, Palgrave Macmillan Houndmills - Basingstoke, Hampshire-New York.

Kledzik Emilia (2015), Komparatystyka między utopia i mitem regionu, „Rocznik Komparatystyczny", nr 6, s. 191-212, https://doi.org/10.18276/rk.2015.6-1.

Putna Martin C. (1998), Česká katolická literatura 1848-1918, Torst, Praha.

Putna Martin C. (2003), Jaroslav Durych, Torst, Praha.

Putna Martin C. (2007), Úvod, w: tenże, Karel VI. Schwarzenberg. Torzo díla, Torst, Praha, s. 7-84.

Putna Martin C. (2010a), Česká katolická literatura 1918-1945, Torst, Praha.

Putna Martin C. (2010b), Obrazy z kulturních dějin americké religiozity, Vyšehrad, Praha.

Putna Martin C. (2011), Václav Havel. Duchovní portrét v rámu české kultury 20. století, Knihovna Václava Havla, Praha.

Putna Martin C. (2012), Křestanství a homosexualita. Pokusy o integraci, Torst, Praha.

Putna Martin C. (2015), Obrazy z kulturních dějin ruské religiozity, Vyšehrad, Praha.

Putna Martin C. (2017), Česká katolická literatura 1945-1989, Torst, Praha.

Putna Martin C. (2018), Obrazy z kulturních dějin Střední Evropy, Vyšehrad, Praha.

Rupnik Jacques (2018), Střední Evropa je jako pták s očima vzadu, Novela bohemica, Praha. 
Rothberg Michael (2013), Między Paryżem a Warszawą. Pamięć wielokierunkowa, etyka i odpowiedzialność historyczna, w: Od pamięci biodziedzicznej do postpamięci, red. Teresa Szostek, Roma Sendyka, Ryszard Nycz, Wydawnictwo Instytutu Badań Literackich, Warszawa, s. 161-188.

\section{| Abstrakt}

\section{LENKA NÉMETH VÍTOVÁ}

Terytorialna historia literatury środkowoeuropejskiej jako spuścizny literackiej i kulturowej monarchii Habsburgów

Martin C. Putna w 2018 roku wydał Obrazy z kulturních dějin Střední Evropy (Obrazy z dziejów kulturowych Europy Środkowej), w których przedstawia spektakularną panoramę wielokulturowości, wielojęzyczności i wielowyznaniowości poszczególnych regionów Europy Środkowej (rozumianej przez niego jako spuścizna kulturowa Austro-Węgier), by móc dalej naszkicować ich „historie idei”: pozwala to na pełniejszą refleksję nad przeszłością tego regionu, a co za tym idzie na budowanie przyszłości w oparciu o te (zapomniane, a niekiedy wyparte) doświadczenia. Autor poprzez propozycję terytorialnej historii literatury pokazuje, jak nadać nowy kierunek - zamkniętej w zaklętym kręgu - dyskusji o konstrukcie Europie Środkowej: eseistyczne obrazy - pomimo fragmentaryczności i subiektywności pewnych odczytań - są ewidentnie krokiem w stronę rozumienia literatury i kultury jako medium pamięci, liczącego na sprawcze oddziaływanie zatrzymanej w nich pamięci (za Astrid Erll genitivus objectivus).

Słowa kluczowe: Putna, Europa Środkowa, Austro-Węgry, historia literatury, pamięć

\section{| Abstract}

\section{LENKa Németh VÍtová}

A Territorial History of Central European Literature as a Literary and Cultural Legacy of the Habsburg Monarchy

Martin C. Putna in 2018 published Obrazy z kulturních dějin Střední Evropy (Images from the Cultural History of Central Europe), in which he presents a spectacular panorama of the multiculturalism, multilingualism, and multiconfessionalism of the 
individual regions of Central Europe (which he understands as the cultural legacy of Austria-Hungary) in order to sketch their "histories of ideas" that allow for a fuller reflection on the past and thus for building a future based on these (forgotten or sometimes suppressed) experiences. By proposing a territorial history of literature, the author gives a new direction to the closed-circle discussion of the construct of Central Europe: the essayistic images - despite their fragmentary and subjective readings - are clearly a step towards treating literature and culture as a medium of memory, counting on the causal effect of the memory they retain (after Astrid Erll's genitivus objectivus).

Keywords: Putna, Central Europe, Austria-Hungary, history of literature, memory

\section{| Biogram}

Lenka Németh Vítová - dr, adiunkt w Instytucie Filologii Polskiej Uniwersytetu im. Adama Mickiewicza w Poznaniu, absolwentka studiów bohemistycznych i polonistycznych na Uniwersytecie im. Masaryka w Brnie (Republika Czeska), tłumaczka tekstów naukowych i literatury pięknej z języka czeskiego i słowackiego na język polski i z języka polskiego na język czeski. Zainteresowania naukowe: teoria i praktyka przekładu literackiego, literatura i kultura krajów Europy Środkowej. E-mail: lvitova@amu.edu.pl

ORCID: 00oo-0003-2134-7655 